\title{
PELATIHAN PEMBUATAN SURAT LAMARAN KERJA MENGGUNAKAN MICROSOFT WORD PADA PKBM DHARMA PUTRA MANDIRI
}

\author{
Rizky Pradana 1), Dwi Achadiani ${ }^{2)}$ \\ Fakultas Teknologi Informasi Universitas Budi Luhur ${ }^{1,2)}$ \\ J1. Ciledug Raya, Petukangan Utara, DKI Jakarta, 12260, Indonesia \\ Email: rizky.pradana@budiluhur.ac.id ${ }^{1)}$, dwi.achadiani@budiluhur.ac.id ${ }^{2)}$
}

\begin{abstract}
ABSTRAK
Pengabdian Kepada Masyarakat (PKM) merupakan hal wajib yang dilakukan oleh dosen, karena mengusung tridharma perguruan tinggi. Pelaksanaan PKM kali ini melibatkan mitra dari Pusat Kegiatan Belajar Masyarakat (PKBM) Dharma Putra Mandiri. Masalah yang dihadapi oleh PKBM ini adalah tidak tersedianya lab untuk praktek komputer, sedangkan di era sekarang ini penggunaan komputer sudah menjadi bagian dari pekerjaan yang tidak terpisahkan. Untuk mengatasi masalah tersebut, maka team PKM memberikan solusi yaitu memberikan pelatihan komputer dasar dengan memanfaatkan aplikasi microsoft word agar siswa-siswi di PKBM Dharma Putra Mandiri mendapat pengalaman mengoprasikan komputer untuk teknik dasar pengoprasian. Untuk meningkatkan kualitasnya selain mengajarkan dasar-dasar penggunaan microsoft word, pada pelatihan ini juga memberikan pelatihan pembuatan surat lamaran kerja dengan memanfaatkan aplikasi ini. Selain pelatihan, peserta nantinya akan mendapatkan sertifikat juga yang bisa dimanfaatkan sebagai surat pendamping ijazah. Berdasarkan pada pelatihan ini para peserta dapat meningkatkan kualitas ilmunya dibidang ICT khususnya pada pembuatan CV dengan menggunakan Microsoft Word. Hasil yang diperoleh dari kegiatan PKM ini terbagi kedalam dua kategori yaitu penilaian terhadap peserta dan team pelaksana. Pada penilaian terhadap peserta, perolehan nilai rata-rata post test sebesar $51 \%$ dengan nilai maksimal 10 dari range 0-10, kemudian perolehan nilai terhadap team pelaksana diperoleh nilai paling tinggi yaitu pada pemberian sarana dan prasarana sebesat $71 \%$.
\end{abstract}

Kata kunci: Pelatihan, PKBM, power, point, microsoft

\begin{abstract}
Dedication to society is obligator by lecturers, because carried on tridharma college. The implementation of the PKM in this time involved counterpart of Community learning activity centers (PKBM) Dharma Putra Mandiri. The Probelem in this PKBM are lack of lab for practicing computer, while in this era computer is a part for doing some works. To solve that problem, team of PKM give some solution, the solution for this problem is give the training of basic computer which utilize microsoft word application for the students in PKBM Dharma Putra Mandiri, this training hopefully the stidents get experience in operating computer. To increase the kuality except do the basics of microsoft word, in this training giving case to create $C V$, wich utilize this application. Besides that, in this training, the participan will get certiicate competency ich can be used as attachment between certificate degree. Based on this training, every participant can increase the kuality in ICT, especially in $C V$ creating with microsoft word application. Result in this PKM sparate in two category, the catogory are assesment for participant and PKM team. The assesment to participant get averages of post test in 51\%, with maimum value is 10 in 0-10 of range, and the best result of assignment for the PKM team is $71 \%$ in infrastructure.
\end{abstract}




\section{PENDAHULUAN}

PKBM Dharma Putra Mandiri merupakan pusat kegiatan belajar masyarakat yang berdiri berdasarkan pada keprihatinan melihat masyarakat lingkungan disekitar yang masih banyak tidak memiliki pekerjaan/pengangguran yang diakibatkan karena tidak mempunyai ijasah yang memadai, serta banyaknya penduduk yang tidak mempunyai keahlian sehingga kurang diserap/produktif bagi perusahaan. Selain itu keprihatinan PKBM Dharma Putra Mandiri ini juga tak lepas dari banyak masyarakat yang masih buta huruf, banyak masyarakat yang drop out SD (terutama usia 25 tahun keatas), banyak lulusan SD tidak melanjutkan ke SMP dan lulusan SMP tidak melanjutkan ke SMA, rendahnya ketrampilan, rendahnya pendapatan masyarakat sehingga tidak mampu untuk melanjutkan pendidikan dan yang terakhir adalah rendahnya keberdayaan perempuan.

PKBM Dharma Putra Mandiri didirikan pada tanggal tanggal 14 Desember 2012 dengan tujuan utama meningkatkan aktifitas pendidikan dan pemberdayaan masyarakat sehingga masyarakat dapat lebih mengoptimalkan kemampuannya untuk bisa meningkatkan kesejahteraan hidupnya dan keluarga. Kegiatan PKBM ini meliputi sekolah Paket C (setara SMA), paket B (setara SMP), paket A (setara SD), serta membuka kelas kelas kursus seperti kursus komputer, kursus bahasa inggris. Selain itu juga membuka bimbingan belajar, kursus membaca/berhitung (calistung) dan kursus lainnya dengan cara bekerja sama dengan pihak ketiga.

Untuk mendaftar dalam PKBM ini syarat-syarat yang diperlukan tidaklah sulit, yaitu usia peserta tidak dibatasi (bebas usia), terbuka juga untuk warga yang sudah bekerja karena waktu pelaksanaan kegiatan yaitu pukul belajar 16.00 - 18.00/19.00 - 21.00. Selain itu juga PKBM ini menerima siswa putus sekolah/drop out/dikeluarkan dari sekolah atau bahkan siswa yang tidak lulus ujian/tidak naik kelas, dan juga memberikan pelatihan tambahan berupa komputer. Lokasi PKBM Dharma Putra Mandiri ini yaitu terletak di Kampung Pondok Serut, Jl. Raya Pondok Kacang, Kel. Pondok Kacang Barat, Kec. Pondok Aren, Tangerang Selatan.

PKBM Dharma Putra Mandiri merupakan PKBM yang terletak di daerah Pondok Kacang. PKBM ini berukuran sangat kecil bila dibandingkan dengan sekolah pada umumnya. Pada PKBM ini tidak terdapat lab komputer, sehingga untuk mengadakan pelajaran yang berbasiskan komputer PKBM ini memiliki keterbatasan fasilitas. Selain fasilitas yang kurang memadai, pembekalan bagi siswa juga diperlukan. Pembekalan itu salah satunya adalah pembekalan dibidang komputer, terutama pengetahuan dasar tentang komputer yaitu microsoft office (Microsoft Word). Terakhir masalah yang diperlukan mitra adalah sertifikat tambahan sebagai bahan tambahan perndamping ijasah program paket yang di ambil oleh siswa-siswi PKBM Dharma Putra Mandiri dalam meningkatkan daya saing di dunia kerja.

Sesuai dengan permasalahan yang dihadapi oleh mitra, solusi yang ditawarkan:

1) Menyediakan tempat untuk pelatihan komputer.

2) Memberikan pelatihan dasar ilmu komputer.

3) Pelatihan yang diberikan adalah pelatihan Microsoft Word.

4) Cakupan materi Microsoft Word yang diberikan adalah pembuatan Curiculum Vitae untuk melamar pekerjaan.

5) Pemberian sertifikat untuk peserta pelatihan guna sertifikat pendamping ijazah bagi para siswa. 


\section{TINJAUAN PUSTAKA}

Pengenalan penggunaan aplikasi Ms. Office khususnya Ms. Word untuk membantu siswa dalam proses pembelajaran. Kegiatan dilakukan dengan metode ceramah, tanya jawab dan praktek langsung. (Putu, 2018). Salah satu alat bantu atau perangkat lunak penyusunan dokumen yang populer digunakan di Indonesia adalah Microsoft Word (Ms. Word). Dari sisi fitur dan fasilitas, MS Word sudah cukup lengkap untuk digunakan sebagai alat untuk membantu penulisan (Setiawan, 2019). Guna memberikan bekal keterampilan dan kemampuan dalam menggunakan dan memanfaatkan perangkat teknologi informasi dan komunikasi menjadi prioritas kebutuhan, meningkatkan kemampuan dasar dalam memecahkan masalah yang akan dihadapi dalam kehidupan di lingkungan desa, meningkatkan pengetahuan mengenai sistem administrasi berbasis komputer, meningkatkan keterampilan mengoperasikan perangkat komputer guna memperbaiki dokumentasi data (Azizah, 2018). Pelatihan progresif dari Microsoft Office seperti Word didefinisikan untuk menyelesaikan masalah tersebut. Pelatihan tersebut diajukan untuk melengkapi keterampilan peserta dalam menyampaikan program pemerintah kepada masyarakat, sehingga tanggapan interaktif dari masyarakat akan menjadi petunjuk semangat untuk melaksanakan program yang disampaikan (Pratiwi, 2018). Microsoft Word (pengolah kata) merupakan bagian dari Microsoft Office yang sering digunakan untuk menangani administrasi perkantoran. Pemanfaatan fitur yang maksimal dapat membantu mempermudah dan mempercepat dalam menangani pengelolaan administrasi (Miftakhur, 2018).

\section{METODOLOGI PENELITIAN}

Metode yang digunakan dalam Pengabdian Kepada Masyarakat kali ini adalah dengan menggunakan metode sebagai berikut:



Gambar 1. Alur Metodologi Penelitian

Pada pelaksanaannya terdapat delapan tahapan. Pertama adalah kunjungan ke lokasi PKBM Dharma Putra Mandiri Tangerang. Pada kunjungan ini dimaksudkan untuk bertemu dengan pihak PKBM guna menanyakan kendala yang dihadapi dalam ranah Pengabdian kepada masyarakat yang diusung oleh team PKM. Selanjutnya setelah bertemu dan berbincang-bincang seputar pendidikan di PKBM Dharma Putra Mandiri tersebut, langkah lanjutnannya adalah menentukan cakupan masalah yang bisa diatasi oleh team guna membantu menyelesaikan masalah yang dihadapi oleh PKBM Dharma Putra Mandiri. 
Setelah medapatkan masalah, langkah yang ketiga adalah studi ustaka dan literatur untuk mendapatkan solusi yang tepat untuk mengatasi maslah tersebut. dapam studi literatur dan pustaka yang dikerjakan, team melihat referensi dari jurnal PKM terdahulu dan buku-buku yang relevan dengan kasus yang dihadapi. Pada kasus kali ini yang dihadapi adalah bagaimana menyusun surat lamaran kerja yang baik dengan berbasis pada microsoft word. Untuk itu referensi yang dipakai adalah jurnal-jurnal dan buku-buku yang terkait dengan tema tersebut. Setelah mendapatkan solusi, langkah berikutnya adalah penentuan desain pelatihan yang akan diberikan. Desain ini terdiri dari desain soal pre dan post test, kemudian desain materi yang akan diberikan dan terakhir desain mekanisme pelatihan.

Pada desain pelaksanaan pelatihan, metode pelatihan yang digunakan adalah learning by doing, yaitu pola pelatihan dengan memberikan praktek langsung yang dipimpin oleh instruktur dan di dampingi oleh asisten instruktur untuk membantu apabila ada peserta yang mengalami kesulitan dalam mengikuti arahan dari instruktur. Langkah selanjutnya adalah pelaksanaan petihan. Pada pelaksanaan pelatihan ini memiliki struktur sebagai berikut:

1. Pemberian sambutan oleh pihak Team PKM dan perwakilan dari mitra, yaitu PKBM Dharma Putra Mandiri.

2. Pelaksanaan pre test yang dilaksanakan serentak, guna mengetahui seberapa besar pengetahuan peserta tentang materi yang akan diberikan, yaitu Microsoft Word.

3. Pemberian materi yang dipimpin oleh Instrutur dan didampingi oleh dua orang Asisten yang terdiri dari satu dosen dan satu mahasiswa (Asisten Lab).

4. Pelaksanaan post test untuk mengukur seberapa jauh peningkatan pengetahuan peserta terhadap materi yang diberikan, hal ini juga menjadi tolak ukur untuk kelayakan pemberian sertifikat pelatihan.

5. Pemberian kuisioner untuk menjadi bahan instrospeksi dari team pelaksana PKM.

6. Penutupan yang diisi dengan prakata dari ketua team dan pembagian sertifikat bagi peserta yang dinyatakan layak mendapatkannya.

Pada bagian akhir yaitu penarikan kesimpulan yang berisi pembuatan laporan PKM yang dilakukan oleh team. Pada tahap ini yang dilakukan adalah melengkapi dokumentasi, pembuatan bab terakhir laporan dan pembuatan paper untuk dipublikasi.

enis kepakaran yang dibutuhkan dalam pelaksanaan Pengabdian Kepada Masyarakat kali ini adalah kepakaran di bidang otomasi perkantoran, yaitu kepakaran di bidang penguasaan aplikasi perkantoran standar yaitu penguasaan aplikasi Microsoft Office, khususnya kepakaran dalam aplikasi Microsoft Word. Dalam hal ini Team yang terdiri dari dua Dosen dan satu Asisten Lab memiliki kompetensi di bidang tersebut, hal ini ditandai dengan sudah banyak Pengabdian Kepada Masyarakat yang dilaksanakan oleh Team dari tahun 2014, serta pengalaman dalam pembuatan berbagai macam laporan dan surat-surat, seperti pembuatan $\mathrm{CV}$ dan lain sebagainya. Selain itu penggunaan Microsoft Word merupakan dasar yang harus dimiliki bagi setiap lulusan Ilmu Komputer.

\section{HASIL DAN PEMBAHASAN}

\subsection{Hasil dan Evaluasi Kegiatan Pelatihan}

Pada pelaksanaannya kegiatan pengabdian kepada masyarakat ini dilaksanakan dalam tiga tahap, yaitu tahap pre test, tutorial dan terakhir post test. Pada tahap pre test para peserta 
diberikan lembar soal dan lembar jawaban untuk dikerjakan dalam jangka waktu 60 menit. Hal ini dimakudkan untuk mengetahui seberapa besar perolehan nilai atau pengetahuan peserta terhadap materi yang akan di berikan. Setelah test dilaksanakan barulah tahap selanjutnya adalah tutorial yang dipimpin oleh satu instruktur dan dua asisten untuk mendampingi para peserta dalam melaksanakan proses learning by doing yang dilakukan selama tahap tutorial.

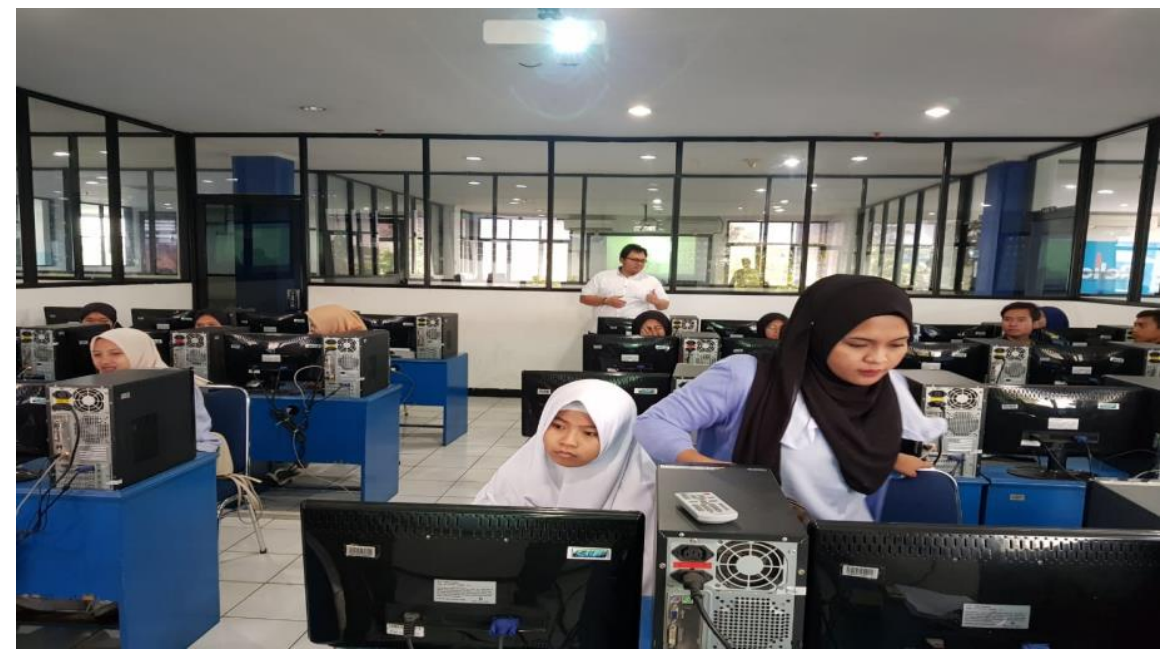

Gambar 2. Pelaksanaan Tutorial

Dalam tahap tutorial ini, pada awalnya diberikan penyuluhan tentang bagaimana membuat curriculum vitae (CV) yang menarik dan berbobot, sehingga sebelum membuat para peserta sudah mendapatkan gambaran tentang apa saja yang harus ditaruh di dalam CV yang akan mereka buat. Proses selanjutnya dari tutorial adalah pendampingan oleh instruktur dan asisten instruktur. Pendampingan ini dimulai dari dasar pembuatan sketsa menggunakan rectangle, sampai pada penempatan tulisan tulisan, yang terdiri dari profile, pendidikan, pengalaman kerja, deskripsi diri, keanggotaan organisasi sampai pada akun sosial media yang dimiliki.

Setelah proses tersebut diselesaikan, tahap selanjutnya adalah pelaksanaan post test. Post test ini dilakukan untuk mengetahui seberapa besar daya serap peserta terhadap materi yang diberikan selama tutorial dilakukan. Berdasarkan perolehan nilai dari pre test dan post test, diperoleh detail nilai sebagai berikut:

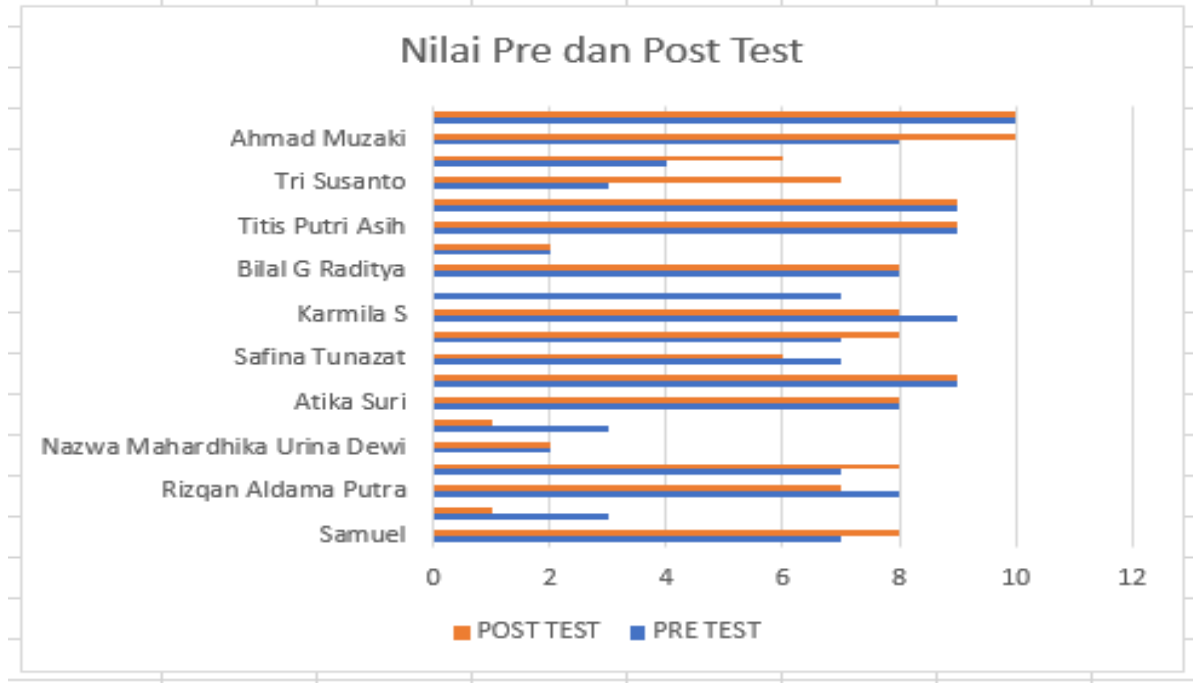

Gambar 3. Detail Nilai Pre Test dan Post Test Peserta PKM 
Berdasarkan perolehan nilai tersebut terlihat bahwa perolehan nilai post test terlihat lebih tinggi dari pada perolehan nilai pre test, dari grafik diatas dapat diambil kesimpulan bahwa setelah pelatihan para peserta mengalami peningkatan pengetahuan. Terlebih dapat dilihat pada grafik berikut ini:



Gambar 4. Resume Nilai Peserta PKM

Selain dari perolehan nilai test, penilaian juga dilakukan terhadap team pelaksana PKM. Penilaian ini dilakukan dengan membagikan kuisioner terhadap para peserta PKM. Isi dari kuisioner ini terdiri dari penilaian terhadap kinerja instruktur, materi yang diberikan serta sarana dan prasarana yang diberikan terhadap peserta PKM. Perolehan nilai tersebut dapat dilihat pada grafik berikut ini:



Gambar 5. Penilaian terhadap Instruktur

Penilaian untuk team pelaksana didasarkan pada kuisioner dengan kriteria:

STS : Sangat Tidak Setuju

TS : Tidak Setuju

$\mathrm{N} \quad$ : Netral

S : Setuju

SS : Sangat Setuju 
Berdasarkan pada penilaian tersebut, perolehan nilai terbanyak terhadap instruktur dan asistensi adalah sebanyak $66 \%$ memberikan nilai Sangat Setuju yang artinya penilaian sangat baik, kemudian dilanjutkan dengan setuju $25 \%$ dan sisanya dari netral sampai sangat tidak setuju yang mencapai perolehan nilai $9 \%$.

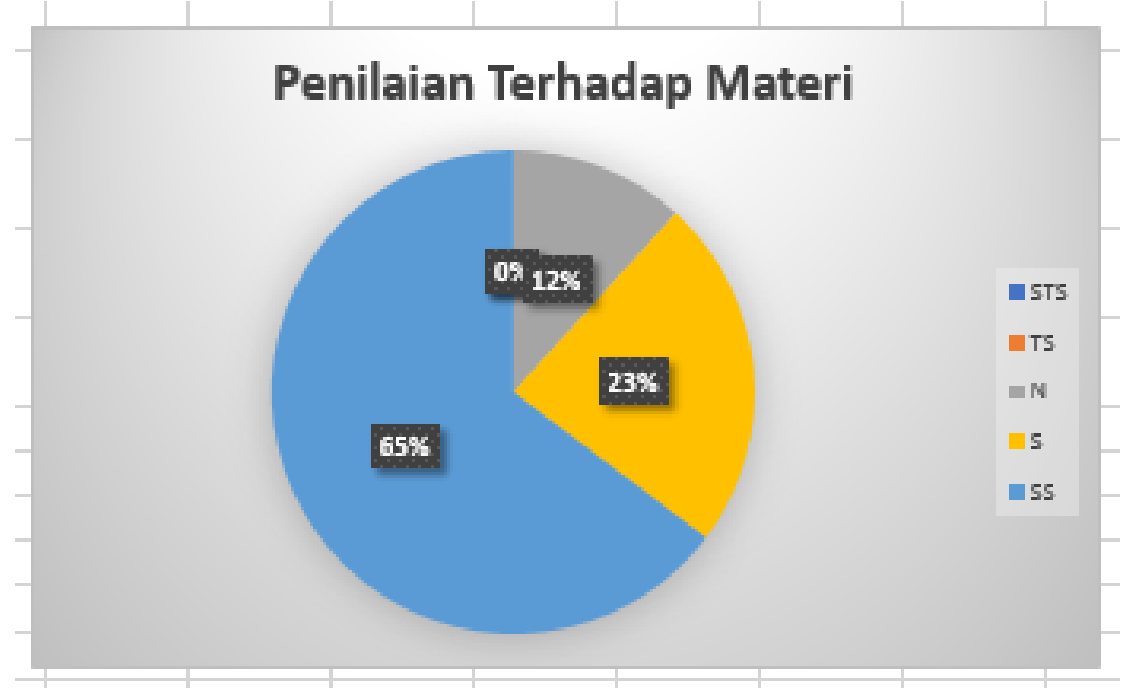

Gambar 6. Penilaian Terhadap Materi Yang Disampaikan

Penilaian terhadap materi yang diberikan, memperoleh nilai tertinggi pada sangat setuju yang artinya sangat sesuai dengan keinginan dari peserta yaitu sebanyak $63 \%$ dan diikuti oleh perolehan nilai setuju yaitu baik sebesar $23 \%$ dan sisanya netral sampai sangat tidak setuju.

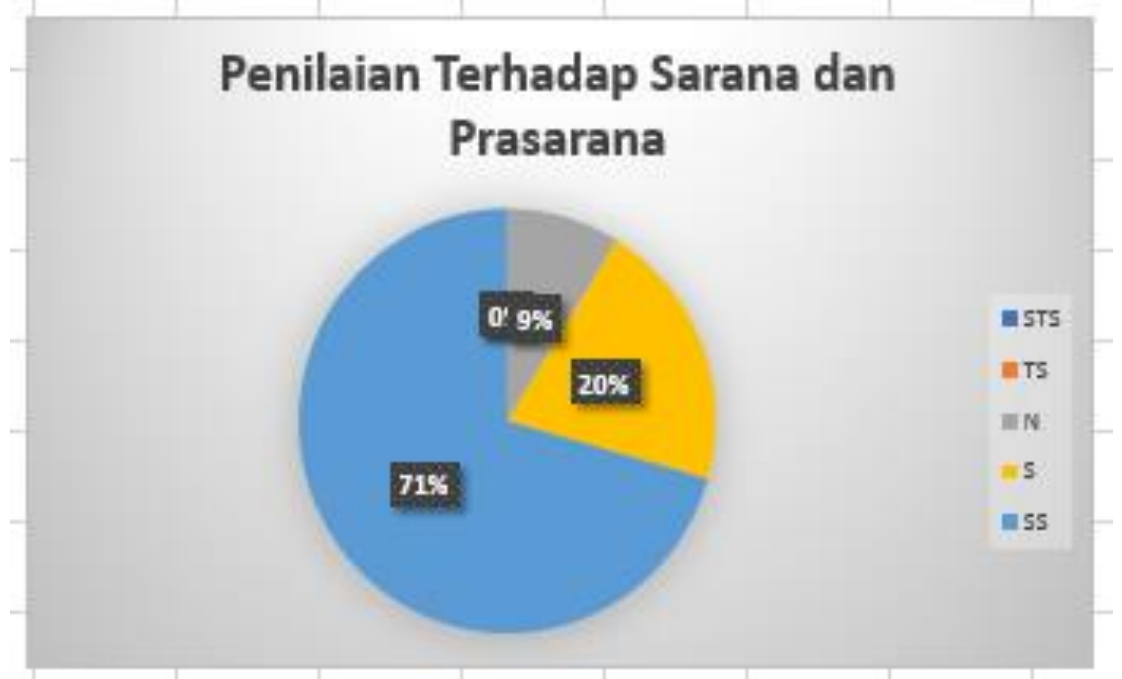

Gambar 7. Penilaian Sarana dan Prasarana

Penilaian terhadap sarana dan prasarana memperoleh nilai tertinggi pada sangat setuju, yang memiliki arti sangat baik, yaitu sebersat $71 \%$, sedangkan yang memberikan nilai setuju (baik) yaitu sebesar $20 \%$ dan sisanya memberikan penilaian mulai dari netral hingga sangat tidak setuju sebesar $9 \%$.

\subsection{Kesimpulan}

1) Kegiatan Pelatihan dilaksanakan dalam tiga tahapan yaitu pre test, tutorial dan post test.

2) Pada penyampaian tutorial secara learning by doing, materi pelatihan yang disampaikan 
meliputi tips membuat $\mathrm{CV}$ yang baik dan menarik, pembuatan blok sketsa area dan terakhir mengisian konten CV di dalam Microsoft Word.

3) Berdasarkan pada kegiatan yang dilakukan dan penilaian terhadap pretest dan postest mengindikasikan adanya peningkatan pengetahuan dari segi IPTEKS dapat diterima dengan baik terlihat dari perolehan nilai rata-rata postest yang meningkat dibandingkan pada saat pretest dengan rata-rata nilai dari 6,5 menjadi 6,7.

4) Hasil evaluasi dari pelatihan ini memperlihatkan bahwa para peserta memiliki tingkat kepuasan yang baik terhadap kegiatan tutorial yang diberikan dengan persentase kepuasan sebesar $91 \%$ untuk nilai gabungan sangat baik dan baik.

5) Kepuasan peserta terhadap materi dan fasilitas yang mencapai nilai yang sangat tinggi juga, yaitu $88 \%$ dan $91 \%$ untuk nilai gabungan sangat baik dan baik.

\section{DAFTAR PUSTAKA}

Putu, Ni Linda Santiari, I Gede Surya Rahayuda, 2018, PELATIHAN MS. WORD PADA SDN 1 GULINGAN, JURNAL PENGABDIAN MASYARAKAT BORNEO, e-ISSN: 2579-9797), VOLUME 2 NOMOR 1 JUNI 2018, Halaman 8-13.

I, Heny, Pratiwi, 2018, PELATIHAN MICROSOFT OFFICE UNTUK KARYAWAN DAN KELOMPOK PKK KELURAHAN SAWAH BARU TANGERANG SELATAN, Sembadha 2018, Volume 01, Edisi 01.

Azzizah, Masdelima, Nur Sahara, Lisna Agustina, 2018, PELATIHAN PEMANFAATAN PERANGKAT LUNAK (MICROSOFT OFFICE WORD, EXCEL, POWER POINT) DALAM KINERJA PENGOLAHAN DATA DI PEMERINTAHAN DESA BAGI KEPALA DESA SE-KECAMATAN BATANG ANGKOLA, e-ISSN: 25981226, Volume 1 Nomor 2 Tahun 2018.

Setiawan, David, Hamzah, Arlenny, 2019, PELATIHAN MS.WORD \& MENDELEY UNTUK PENULISAN KARYA ILMIAH DOSEN FAKULTAS TEKNIK UNILAK, DINAMISIA - Jurnal Pengabdian Kepada Masyarakat, Vol. 3, No. 1 Juni2019, Hal. 172-179.

Pratiwiheni, (2018), Pelatihan Microsoft Office Untuk Karyawan dan Kelompok PKK Keluraham Sawah Baru Tangerang Selatan, Tersedia pada: Sembadha 2018, Vol 01 Edisi 01 Seminar Hasil Pengabdian Kepada Masyarakat PKM Stan.

Kwanti, Lida Perdana dan Tripustikasari Eka, (2019), Pelatihan Komputer Dasar Bagi Kader PKK dan Posyandu di Desa Patikraja, Tersedia pada: Madani: Indonesian Jounal of Civil Society, Vol.1, No.1, Agustus 2019, PP. 17-23. 